\title{
Intra-Community Trade in Agricultural Products: Options for Trade Volume Expansion by ECOWAS
}

\author{
G.O.Onogwu $^{1 *}$ Ibe, Justina Chituru ${ }^{2}$ Arua, Rosemary Nnedinso ${ }^{3}$ \\ 1. Department of Agricultural Economics and Extension Services; Federal University Wukari, 200 \\ Katsina-Ala Road, P.M.B 1020 Wukai, Taraba State, Nigeria. \\ 2. Department of Agricultural Economics, University of Nigeria, Nsukka, Nigeria. \\ 3. Department of Agricultural Economics, University of Nigeria, Nsukka, Nigeria. \\ *E-mail of the corresponding author: ngwugodwin@gmail.com
}

\begin{abstract}
The study analyzed agricultural product trade data to ascertain the extent of involvement of ECOWAS in community trade between 2013 and 2017. The extent to which members fulfilled the regional trade co-operation policy objective of expanding the volume of intra-community trade is gauged by computed trade indices. Each index measures intra-community trade as a share of total trade, and takes values between 0 and 1 . The value is 0 , if trade is truly intra-community carried out by all or most members; and 1, if trade is inter-regional, most trade being carried out by few community members. Value of annual index were influenced by cases of none, under or over reporting by member nations. Analysis revealed that intra-community trade occurred more in animal than food products, while vegetable products accounted for less. It is recommended that ECOWAS member nations should seek and utilizing foreign direct investment in development of agricultural sector to improve value chain in addition to increasing and sustaining intra-community trade volume. Besides, reports of intra-community exports and imports of agricultural products should be accurate, and no member should import from other regions where sub-community members are suppliers.
\end{abstract}

Keywords: Agricultural Product Sub-sections, ECOWAS, Intra-Community Trade, Extent.

DOI: $10.7176 / \mathrm{DCS} / 9-1-08$

\section{Introduction}

In 1. Formation and Nations of ECOWAS

Sequel to the call by the Organization for African Unity (OAU) heads of state summit on all its member states to form regional groupings for the purpose of accelerating their economic development, the treaty establishing ECOWAS was signed in Lagos Nigeria. The Economic Community of West African States (ECOWAS) is a regional organization of 15 West African countries established on 28 May 1975. The administrative headquarters (secretariat) of ECOWAS is located in Abuja along Yakubu Gowon Cresent in Asokoro district of the city. There are currently 15 member states in the Economic Community of West African States. The founding members of ECOWAS were: Benin, Côte d'Ivoire, Cabo Verde Gambia, Ghana, Guinea, Guinea-Bissau, Liberia, Mali, Niger, Nigeria, Senegal, Sierra Leone, Togo, and Burkina Faso (https://www.abuja-ng.com/ecowas-secretariat.html). Currently, member countries making up ECOWAS are Benin, Burkina Faso, Cape Verde, Cote d' Ivoire, The Gambia, Ghana, Guinea, Guinea Bissau, Liberia, Mali, Niger, Nigeria, Sierra Leone, Senegal and Togo (http://www.ecowas.int/about-ecowas/basic-information/).

\subsection{Reasons for setting up ECOWAS}

Considered one of the pillars of the African Economic Community, ECOWAS was set up to foster the ideal of collective self-sufficiency for its member states. As a trading union, it is also meant to create a single, large trading bloc through economic cooperation. Its main goal is the promotion of the economic integration among its members. The overall objective of ECOWAS integration arrangement was to derive the benefits of co-operation which could be economic, political, and or social (ECOWAS, 1975). Trade co-operation objective was to expand the volume of intra-community trade following the removal of both tariff and non-tariff barriers to trade on goods originating from member countries. However, intra-ECOWAS trade flows have remained very low. The trade liberalization process was expected to be implemented through such interventions like free international trade, common external tariff wall, consolidation or freezing of custom duties, and non-tariff barriers to intratrade (ECOWAS, 1981b). Others include gradual phasing out of duties on industrial products from community projects over a period of 6-10 years at $10-16.6 \%$ annual rates of reduction depending on the classification of 
member states based on the level of development, location and importance of customs revenue.

\subsection{Trade Regimes within ECOWAS}

The issue of low intra-community trade in ECOWAS has always been of concern to regional policy makers. As is evident, the ECOWAS intra-community trade moved from $11.6 \%$ of the total regional trade to $12.7 \%$ in 2003 before it declined in subsequent year. However, it moved up again and settled at $12.5 \%$ of the total external trade in 2006 (ECOWAS statistical Bulletin, 2008). Besides, the rate of intra-ECOWAS trade measured as percentage of total intra, divided by total trade dwindled henceforth from 2011 through 2016 at 9.5, 9.3, 12.6, 9.8, 12.1, and 11.5, respectively. This gives an average intra-ECOWAS trade rate of 10.8\% for the 6 year period, 2011 to 2016 (http://www.ecowasstats.ecowas.int/Browsebydatatableindicators.aspx?id=32). The implication of this is that ECOWAS member nations engage in little trade among themselves, even where without sufficient intracommunity trade, economic integration might be limited and the need for a common currency might not be justifiable. The picture of the extent to which ECOWAS nations pursue regional integration in terms of volume of patronage to trade in animal, vegetable and food products in line with the co-operation agreement of expanding trade volume within the sub-region is not known. This gives rise to questions such as: - (i) Which ECOWAS countries export or import what volume of agricultural products from the sub-region? (ii) Which agricultural product sub-sections are mostly trade by which member nations? Though intra-ECOWAS trade flows have remained very low to date Foroutan and Pritchett, Ogunkola, (1993; 1995; 1998). (iii) Which of the ECOWAS members account for low trade within the sub-region. (iv) Which sub-regional countries are responsible for the level of intra-community trade recorded in agricultural product subsections? These are the gaps the study aims at filling.

\subsection{Research Objectives and Theoretical Framework}

The broad objective of this study is to evaluate ECOWAS members' extent of trade in agricultural product subsections for the period 2013 to 2017. The specific objectives were to:-

(i) Examine sub-regional exports and imports in animal, vegetable and food products within the period under review.

(ii) Identify the agricultural products mostly traded and members involved in the trades.

(iii) Evaluate the intra-community trade indices for members and agricultural sub-sections - (animal, vegetable and food products), for the period under review.

The study followed the theoretical framework of Wales, (2002) which posited that factor endowment has a role to play in predicting production and trade pattern. Hitherto, factor endowment refers to the skills and abilities of a country's workforce, the natural resources available within its borders (minerals, fertile land), and sophistication of its capital stock (machinery, infrastructure, and communication system). The theory assumes that relative supplies of factors of production determine international trade patterns of countries. Therefore, every ECOWAS member can only export animal, vegetable and food products produced by her abundant factors. Again, Heckscher-Ohlin-Samuelson model (HOS, 1933) conceptualized international trade as a phenomenon consisting in each country exporting goods and /or services in order to improve growth, through comparative advantage, technology and competitiveness. This framework, otherwise referred to as inter-industry trade, was considered by economists as the most relevant for predicting the pattern of trade existing among nations. Again, standard customs union theory, as articulated by Viner, (1950), predicted increased inter-industry specialization, and trade, though its wake brought serious adjustment frictions. The theory of comparative advantage envisaged in ECOWAS sub-region is mostly concerned with efficient use of resources for producing a limited number of very homogenous commodities, and in this regard, animal, vegetable and food products.

\subsection{Methodology}

The study considered the nations of Economic Community of West African States (ECOWAS). They are located between Latitudes $0^{\circ} 26^{\prime}$ and $20^{\circ} 31^{\prime}$ North; and Longitudes $10^{\circ} 36^{\prime}$ East and $20^{\circ} 19^{\prime}$ West. The northern border of West Africa is the Sahara desert. To the west and south of West Africa sits the ocean, which serves as another natural border. And in the southeastern corner of West Africa are the Cameroonian Mountains and highlands that lie along the border between Cameroon and Nigeria. The study focused on the extent of intra-community trade in agricultural product subsections - the animal and vegetable fats and oils, and other cleavage products among major trading community members. (Benin, Burkina Faso, Cape Verde, Cote d'Ivoire, Ghana, Gambia, Guinea, Guinea Bissau, Liberia, Mali, Niger, Nigeria, Senegal, Sierra-Leon, and Togo).

Data for this study were collected from secondary sources. All regional exports and imports of animal, vegetable and food products were collected from Trade Analysis and Information System (TRAINS). The data were elicited following a well-defined job queries on agricultural trade carried out by ECOWAS regional members within the years under review. UNCTAD TRAINS is a data base that connects UNCOMTRADE, and WTO, 
among other data bases; thus enables retrieving of trade data available in either of the data bases. The data were analysed, organised and presented to guide policy decisions on sustaining agricultural trade by community members given the trade liberalization policy framework enjoyed by all members. Descriptive statistics were used to achieve objectives (i) and (ii), while objective (iii) was achieved by employing an intra-community trade model.

\subsection{Analytical Procedure and Model Specification}

Intra-community trade indices for total agricultural product and sub-sections in the community for the countries and years under review were obtained through evaluating the extent to which total regional exports $\left(T R E_{E C O W A S}\right)$ in a particular year was offset by imports of the same commodity by member nations'. Since this index measures intra-community trade as a share of total trade in agricultural products and sub-sections $\mathrm{j}$, it takes values between 0 and 1 . The value is 0 , if all trade is intra-community; and 1, if trade is inter-regional. The index can be influenced by factors such as, none reporting, under reporting or over reporting. This is modelled thus: -

$$
I R T_{J}=1-\frac{T R E_{\text {ECOWAS }}-T R I_{\text {ECOWAS }}}{T R E_{\text {ECOWAS }}^{M}+T R I_{\text {OECOWAS }}}
$$

Where;

$$
\begin{aligned}
& I R T_{J}=\text { Intra-community Trade (in Product, } \mathrm{J} \text { ) } \\
& T R E_{\text {ECOWAS }}=\text { Total Regional Export of product J by ECOWAS } \\
& T R I_{E C O W A S^{M}}=\text { Total Regional Import of product J by ECOWAS }
\end{aligned}
$$

\subsection{Results and Discussion}

The facts of the evaluated extents of intra-community trade in agricultural products sub-sections are hereunder presented in table 1. It shows the ECOWAS regional members export and import trade for the five years running 2013-2017; the values of total exports and imports as well as intra-community indices of agricultural products. The table x-rays nations that participated in regional trade over the years under review. Table 2 presents the results of the computed extent of Intra-community Trade in Agricultural Product Subsections and total extent of intra-community trade in agricultural products by ECOWAS Members (2013 to 2017).

\subsubsection{Sustainability of Regional Agricultural Trade by ECOWAS Member Nations}

From the indices of table 1, it can be deduced that ECOWAS members engaged in intra-community trade more in 2017, while the nations account for lesser trade in 2014. Hence, in 2013, 2015, 2016, and 2017, the regional exports were offset by imports of member nations, though all values of trade indices tend towards one, indicating low, but evident of intra-community trade. 


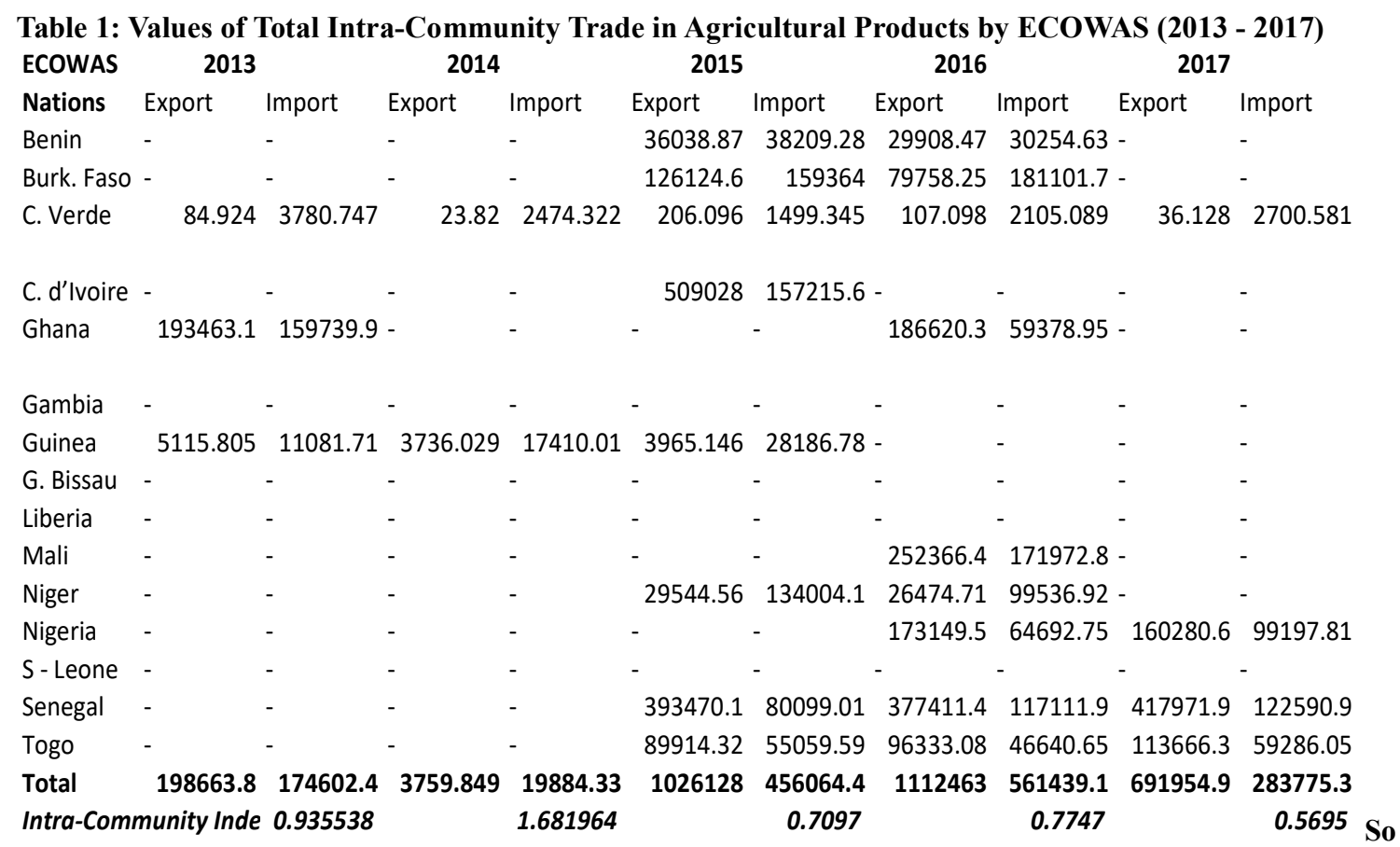

urce: TRAINS, 2017; Computed by Authors, 2018.

\subsubsection{Extent of Intra-Community Trade in Agricultural Product Sub-sections}

The details of intra-community and intra-community trade indices of each ECOWAS nation in agricultural product sub-sections are presented in Appendix 1-5. The product sub-sections covered are: (i) Animal products, (01-05); (ii) Vegetable products, (06-15); and (iii) Food products (16-24). It is evident from data and computed indices that intra-community trade occurred majorly in animal products, corresponding to agricultural subsection (06-15) with an average trade index of 0.726; followed by food products sub-section (16-24), with an average intra-community index of 0.938 . There was no intra-community trade in section (01-05) with an average index of 1.009, possibly due to inter-regional trade, over reporting or under reporting of exports or imports by member nations, in which cases, exports falling short of imports and vice versa. However, the average intracommunity trade index for total agricultural trade stood at about 0.935 for the period under review.

Table 2: Extent of Intra-Community Trade in Agricultural Products by ECOWAS (2013 - 2017)

\begin{tabular}{|l|l|l|l|l|}
\hline Year & \multicolumn{3}{|c|}{ Intra-Community Trade Indices } & Total Intra-Community Trade \\
\cline { 2 - 5 } & Animal Products (01-05) & Vegetable Products (06-15) & Food Products & All Products \\
& & & $\mathbf{( 1 6 - 2 4 )}$ & \\
\hline $\mathbf{2 0 1 3}$ & $1.713^{*}$ & 0.556 & 0.782 & 0.936 \\
\hline $\mathbf{2 0 1 4}$ & 0.198 & $1.578^{*}$ & $1.950^{*}$ & $1.682^{*}$ \\
\hline $\mathbf{2 0 1 5}$ & 0.927 & 0.594 & 0.721 & 0.710 \\
\hline $\mathbf{2 0 1 6}$ & 0.329 & $1.005^{*}$ & 0.846 & 0.775 \\
\hline $\mathbf{2 0 1 7}$ & 0.461 & $1.312^{*}$ & 0.391 & 0.570 \\
\hline
\end{tabular}

Source: Computed by Authors, 2018; from TRAINS data, 2017.

* = Instances of nil intra-community trade 


\subsection{Summary and Conclusion}

On the average, the intra-community indices for animal, vegetable and food products for the five year review period stood at $0.726,1.009$, and 0.938 , respectively. This implies that the region engaged in more of the trade in animal than food products, but nil in vegetable products. The computed intra-community trade indices for total agricultural trade for the years under review show that there were no intra-community trade in the year 2014 . This means that the nations of ECOWAS did not deliver on the policy objective of expanding trade for the year. Put differently, intra-community trade were not sustained in the year. This could be attributed to non-reporting of trade that actually took place. Besides, there were evidence that ECOWAS members engaged in more intracommunity trade in 2017 , given the approximate total agricultural intra-community trade index of 0.570 for the year. In 2013, 2015, 2016, and 2017, intra-community exports though were able to offset the imports, all values of trade indices were tending towards one, indicating presence, but low intra-community trade. The cases where import values were more than exports', are likely evidence of under reporting or over reporting of exports or import, respectively. It is evident from analyzed data that four ECOWAS members (Gambia, Guinea-Bissau, Liberia, and Sierra-Leone) did not participate in regional trade within the five years review period. As well, three community members (Cote d'Ivoire, Ghana, and Mali) participated only once in community trade within the period. The major consistent drivers of intra-community trade among ECOWAS within the period under review were Cape Verde, Senegal and Togo, while Benin, Burkina Faso and Nigeria accounted for less.

\subsection{Recommendation}

Based on the trend of data and computed extent of intra-community trade, the study recommend the following measures to aid in deepening and sustaining regional integration through intra-community trade:-

(1) ECOWAS member nations should isolate and report intra-community exports and imports of agricultural products among others.

(2) Foreign direct investment should be sought and utilized in the development of agricultural product value chain and sub-sectors to increase tradable products, to improve and sustain intra-community trade volume.

(3) ECOWAS member that does not participate in sub-community trade at all or may not have participated at least thrice in regional trade for a period of five years should be sanctioned.

(4) ECOWAS members that import agricultural products from other region where sub-community members are suppliers should be sanctioned.

Acknowledgement: The authors are grateful to the Nigerian Association of Agricultural Economists (NAAE, Kada, 2018) for the constructive criticisms during conference, which informed this manuscript.

\section{References}

ECOWAS (1975). Treaty of the Economic Community of West African States, ECOWAS, Lagos.

Foroutan, F. and L.Pritchet. (1993). "Intra-Sub-Saharan Trade: Is it too little?" Journal of African Economies Vol.5, No. 1

Heckscher, E. F. and B. Ohlin. (1933). Factor-Endowment and Factor Proportion Theory Harvard University Press

https://www.wits.worldbank.org. Retrieved, 2018.

https://www.abuja-ng.com/ecowas-secretariat.html Retrieved, 2018.

http://www.ecowas.int/about-ecowas/basic-information/ Retrieved, 2018.

http://www.ecowasstats.ecowas.int/Browsebydatatableindicators.aspx?id=32 Retrieved, 2018.

UN COMTRADE Data; Result Available online at https://www.wits.worldbank.org.

Vernon, R. (1966) “International Investment and International Trade in the Product Cycle”, Quarterly Journal of Economics, 80, No.2, pp 190-207.

Wales, T. (2002) Labour Market Effects of Intra-Industry Trade.: Evidence for the UK Vol. 138 pp207-227 